\title{
Sport entrepreneurship: A synthesis of existing literature and future perspectives
}

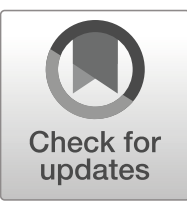

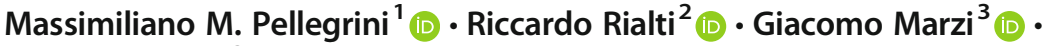 \\ Andrea Caputo ${ }^{3}$ iD
}

Published online: 21 February 2020

(C) Springer Science+Business Media, LLC, part of Springer Nature 2020

\begin{abstract}
Sport entrepreneurship is progressively emerging as an extremely significant stream of research. Accordingly, scholars are increasingly assessing how sportspeople tend to have higher entrepreneurial orientation and intentions than the average. In a similar fashion, scholars have also observed how sport-related entrepreneurial ventures can have a positive effect on community development. Nonetheless, this literature stream is still fragmented, lacks a proper systematization, and needs an identification of its intellectual structure and research themes. Hereby, we performed a bibliometric analysis of 86 papers and a systematic literature review on the most influential papers belonging to the pertinent literature. Results show that a 4-cluster structure exists for sport entrepreneurship: its theoretical definitions and internal factors fostering it (cluster 1), environmental factors may foster it (cluster 2), pedagogical approaches and education (cluster 3), and finally its impacts, especially in terms of community development and social benefits (cluster 4). From these findings, a framework to help both scholars and practitioners approaching the topic was developed.
\end{abstract}

Keywords Bibliometric $\cdot$ Entrepreneurship $\cdot$ Entrepreneurial ventures $\cdot$ Sport entrepreneurship $\cdot$ Sport-related initiatives

Massimiliano M. Pellegrini

massimiliano.pellegrini@uniroma2.it

1 Management and Law Department - School of Economics, University of Rome "Tor Vergata", Rome, Italy

2 Department of Science for Business and Economics, University of Florence, Florence, Italy

3 Lincoln International Business School, University of Lincoln, Lincoln, UK 


\section{Introduction}

In this century, the sport industry has exponentially increased its impact on the economic development and with that the interest received by the academic community (Ratten 2010, 2012a, b).

The economic impact of sports in modern society is indeed undeniable. In the EU28, the sport sector employs more than 1.7 million people, and carries a growth of $2.1 \%$ between 2012 and 17 compared to $1.1 \%$ of all sectors (Eurostat 2018). For this reason, it has a prominent attention in EU agenda (European Commission 2017). Moreover, sport events such as the Olympics (Gammon and Robinson 2003) or FIFA World Cup (Briedenhann 2011) nowadays move extremely high levels of investments with positive spillovers in terms of infrastructure improvements and benefits for tourism, leisure, or sport-related corollary activities to be offered to the fans (Devine et al. 2010; Terjesen 2008) and on a grander scale in terms of local economies and communities (Ciomaga 2013). Even just considering capitals directly invested in these events, especially for mainstream sports, amounts are similarly high. This is without even considering the returns that come from the associated branding and merchandising (Ratten 2017; Toffoletti and Thorpe 2018). An exemplary case is the deal closed by the Italian football club Juventus, which in 2018 safely secured the transfer of the multiple award-winner Cristiano Ronaldo for a bid that only nominal worth of $€ 100$ million. However, such a deal is more than just related to "on-the-field" motivations. While Ronaldo is today probably one of the most skillful football players of his generation, Juventus also hopes to exploit the "CR7" effect - Ronaldo's personal branding (Ahmed 2018, September 16). During 2018, indeed, the merchandising and revenues of Juventus Football Club have steadily risen - confirming that it is quite a strategic move of the club.

However, as in any other industry, when competition starts to be fierce, it is necessary to keep renovating the competitive advantage. One way to do so is the recombination of the resources at the disposal of a company. Or, in other words, innovating (Penrose 1959). Innovation is an output of a larger process that implies the ability to convert an idea into a (successful) innovation, thus creating value from it (Schumpeter 1942). In this perspective, entrepreneurship is indeed the discipline that addresses such concerns. For this reason, also in relation to sport and sport-related activities, inquiring features of entrepreneurship is important (Ratten 2012a). In addition, the very ontology of sport management is based on dealing with uncertainty (Neale 1964) as outcomes of any competition are unknowable a priori. While sport professionals and managers may work hard to construct a solid base for the success, this is never assured (Chadwick 2009).

Although all these considerations, the entrepreneurship topic seems to have received minimal attention from sport management in academic studies (e.g. Chalip 2006; Shilbury 2011b; Ciomaga 2013). Accordingly, it is important to address entrepreneurial Aspects in relation to sport and to contextualise them within the sport industry - further stimulating a debate for sport management discipline.

Readapting the several aspects of sport entrepreneurship, this is related to spot, create, and pursue novel opportunities or perform any innovative activities in a sport context, with a central focus on the human aspect (Ratten 2012b). To fully understand the implications of this definition, it is useful to relate it to the traditional definition of 
entrepreneurship gave by Shane and Venkataraman (2000) in their famous foundational paper of the whole entrepreneurship field. Entrepreneurship focuses on "how, by whom and with what effects opportunities to create future goods and services are discovered, evaluated, and exploited" (p. 218).

In both definitions, a forefront aspect is related to the source of opportunities, so from where they emerge. The existence of business opportunities is indeed fundamental in order to start any entrepreneurial venture. Following the metaphor model developed by Cardon et al. (2005), it seems that entrepreneurship in sport activities may be associated with an 'active seeking conception'. Opportunities and new solutions for sports and sports-related activities derive mostly from the ability of people passionate about a sport to interpret the consumers' needs, especially those not completely satisfied (Jones et al. 2017). For example, being a fan of the sport or practicing it facilitates this interpretation since these needs are experienced in first person. Similarly, it may be observed how a sportsperson may have a deeper knowledge about the techniques to practice such a sport and how to make training easier.

In a second dimension in both definitions, it is indicated that such opportunities should be transformed into actual value, a process that involves 'tying' the contextual conditions to a factual entrepreneurial behaviour. As much as in other industries (e.g. technological advancements, Biotech, ICTs, STEM, agriculture/rural sector), entrepreneurship and its features are industry-specific (Ratten 2010). Indeed, precise "rules of the play" and "macro-cultures" (Fayolle et al. 2010) exist and are made of a common understanding/perception of the environment. E.g. same suppliers, customers, and subsidiaries (Ratten 2012b). From such a knowledge of the "rules of play", sportspersons may draw value from their passion and expertise. For instance, it was observed how female athlete entrepreneurs adopt similar strategies to integrate their lifestyle in their way of managing a venture amidst competition (Ratten and Miragaia 2019). Another case is the management of 'icon players' (Chadwick 2009). However, the structure of the industry may also hinder the 'actualization' of the value of an opportunity. The sport industry is populated by a mix of public and private actors (Chalip 1995) that may generate tougher competition than in other industries, without considering the low entry barriers as for a small reality, the initial costs can be limited. In some cases, the start of a sport entrepreneurial venture may also be constrained by the availability of the right infrastructure. But, a practitioner may know better than anyone else the existing public/private infrastructures that can be used to start a new venture (van Bottenburg and Salome 2010).

Thirdly, there is also a personal dimension related to the actors of the process. In general, entrepreneurs show some common internal characteristics such as resilience, high levels of internal locus of control, and high needs for achievements. It is possible to say that this is also true for sport entrepreneurship (Jones and Jones 2014; Ratten 2015). Through their training, sportspersons are surely prone to acquire entrepreneurial characteristics as these individuals are proactive and resistant to stress, as demonstrated by several researches (e.g. Mitchell 2005; Neergaard and Krueger 2008). However, it would be important to understand how to move from this potential state to an actual entrepreneurial behaviour towards creating a new venture or, in any case, acting entrepreneurially. This consideration implies the need to study the entrepreneurial intentions of sportspeople and how to stimulate them (Teixeira and Forte 2017). For example, much research (e.g. Ratten 2010) has suggested governmental actions and 
policy may play a role as several initiatives aim at supporting athletes after their sporting careers. In this direction, the International Olympic Committee set up the Athlete 365 initiative and its service Career +- a career-transition service and business accelerator aimed at helping athletes in starting a business. Other cases and needs are those related athletes, who after their 'active' sport career, or in a later stage in life may want to enter a managerial/entrepreneurial position in the same sport/industry (Kautonen et al. 2017).

This attention to the personal sphere of sport entrepreneurs, consequentially, calls for entrepreneurship education and pedagogies that should be also considered to ensure a proper approach within the more general sport education (González-Serrano et al. 2018). Some studies (e.g. Ratten 2012b; Ratten 2015) showed how sport courses are or should be structured. However, indirectly, entrepreneurial education could also benefit from looking more closely into the insights of sport education and this relates to entrepreneurial intentions of students (Stambaugh and Mitchell 2018).

Finally, even if not directly analysed in the original paper of Shane and Venkataraman (2000), the definition also considers the 'effects' of the process. Everything creating value can be considered an entrepreneurial outcome (Baumol 1996), thus not necessary and only the production of a profit. Especially for sport entrepreneurship, this aspect is quite relevant. For example, many sport activities, at least those at a local level, may not have a for-profit scope (Shilbury 2011a; Hemme et al. 2017; Misener and Misener 2017). Yet, sports can have beneficial spillovers for the local development both in terms of economic values, creating employment (Tyson et al. 2005), and of social and community values. For example, the intercultural exchange (Lyras and Welty Peachey 2011). This also represents one of the central points in the EU agenda for sport that is to understand and stimulate a major debate about sport societal outcomes. Indeed, sport is perceived as central for social inclusion and diplomacy promotion and for improving environment and health-related issues (European Commission 2017). However, this possible hybrid or blurred nature of the sport industry poses several problems in terms of legitimisation (Chalip 2006). Different national systems may perceive the industry in radical different manners and thus mixed approaches to policies and political support received, but also different mind-sets and profit-orientation of the actors involved in it (Chadwick 2009). While the original core of the sport management discipline is permanently tied to a social dimension, it would be too naïve to consider the whole industry as not professional (Shilbury and Ferkins 2011).

Despite this large overview, the field of sport entrepreneurship is still in its infancy and yet the overall sport management discipline still struggles in getting a full legitimisation in the academic debate (Chalip 2006; Shilbury 2011a, b). Just considering when the first proper definition of the field emerged (Ratten 2010), it is quite evident that strong and shared paradigms for sport entrepreneurship are far to be established and thus the field remains quite fragmented (Ratten 2012a). In particular, it is observable that several researches (Ratten 2010, 2012b, 2015) have focused on trying to attain a definition of sport entrepreneurship. The contributions of these papers are trying to identify the role of entrepreneurship within the sport management field. As a matter of fact, the extant literature on sport management focused on large sport ventures, e.g. football teams, national leagues (Chadwick 2009;) but neglects the management of smaller initiatives (Shilbury 2011a). Next, a growing field is observing 
the importance of the interplay between individual/small organizations and the government in the development of new sport businesses (Shilbury and Ferkins 2011). In fact, governmental support is necessary as the government is frequently the infrastructure provider (Chalip 1995, 2006). Finally, some research started to consider how sport entrepreneurial ventures may replace governments in creating social value (Ratten 2017). However, as it is possible to observe, sport entrepreneurship is still an elite topic even within sport management literature (Ciomaga 2013). This phenomenon is related to the fact that until recent times, the economic importance of the sport industry was not fully recognized by either scholars or practitioners.

Thus, the actual academic momentum calls for a major attention to the topic and what has been already done should not be forgotten. In this light, our paper with a bibliometric approach assesses the knowledge structure through a systematization of the contributions. Bibliometric studies have demonstrated their helpfulness in a broad range of fields, such as management (Mackenzie 2008), entrepreneurship (Sassetti et al. 2018), innovation (Fagerberg et al. 2012; Marzi et al. 2017), and international business (Dabic et al. 2014). Bibliometrics also help scholars to separate individual streams of research from the 'tangled forest' of the scientific proliferation.

Consequently, we performed our bibliometric analysis on a final set of 86 papers showing main descriptive characteristics as well their aggregations around common topics, individuated through a cluster analysis.

The paper contributions are at least threefold. First, thanks to a systematization of the contributions, we have clearly highlighted the knowledge structure of the sport entrepreneurship field. Our work helped in assessing the evolutions and trends of this newfound academic field and thus facilitated the reply to the overarching and fundamental research question: how can sport and sport-related activities be performed entrepreneurially? Our study offers a more solid basis to understand what has been done and what is still to be discovered in the field of sport entrepreneurship. However, researchers in the wider academic debate of entrepreneurship may also benefit from the elements emerging from the case of sports and sport-related activities. As shown through the analysis of our clusters, sport entrepreneurship is an excellent context to study specific policies or environmental conditions that foster entrepreneurship (e.g. Briedenhann 2011; Tyson et al. 2005), and this is also thanks to the involvement of local communities (Bjärsholm 2017), along with obvious social outcomes (Lyras and Welty Peachey 2011). Similarly, sport entrepreneurship can help to understand entrepreneurial intentions (do Paço et al. 2013), motivational aspects, and entrepreneurial passion with the specific attention to cases of athletes who actually become entrepreneurs (Ratten 2010).

Second, through our proposed interpretative framework, practice-oriented contributions and implications for practitioners can be also inferred. For example, the framework summarizes how sportspeople or fans may turn into entrepreneurs. Thus, it indicates a possible 'path' that sportspeople may have to follow to attain such a goal. Another aspect of the framework is the consideration of the role of education as an accelerator. Specifically, in relation to the main skills that a sport entrepreneur may need, the framework indicates the topics that should be tackled in sport (entrepreneurship) education programs. Finally, our framework indicates and reviews best practices for using sport as a developmental strategy and conflict-resolution/ attenuation instrument (Cohen and Peachey 2015). 
Finally, based on our clusters' analysis, we propose an initial set of future research questions and avenues to further evolve the sport entrepreneurship field. In comparison to other valuable systematization efforts (e.g. Huertas González-Serrano et al. 2019) that have opened the debate about the sport entrepreneurship as sub-field, our contribution will help to offer specific foundational building blocks for the field.

The paper is structured in six sections, including this introduction. The following section is related to the explanation of the methodology to perform the bibliometric analysis, while section 3 reports its descriptive and aggregate findings. Section 4 is instead dedicated to the explanation of the cluster analysis to clearly show trends and knowledge structures that have emerged so far. In particular, we commented on the contributions for each of the four clusters. Section 5, drawing from the insights of previous sections, models an interpretative framework able to highlight relationships and fundamental topics for the sport entrepreneurship field, while also indicating possible gaps and future research avenues. The last section is dedicated to the conclusions.

\section{Bibliometric analysis}

To perform an accurate analysis of sport entrepreneurship as a field of research, a bibliometric analysis based on the visualization of similarities (VOS) technique (van Eck and Waltman 2009; van Eck et al. 2006) has been used together with a systematic literature review protocol (Smart et al. 2003).

Indeed, the bibliometric approach allows a classification as well as visualization, producing a spatial representation of results and mapping the knowledge in an almost geographical manner (Zupic and Čater 2015). Among the many approaches based on surveying and analysing literature data, this one in particular is broader in scope and can account for more fields of research. On the other hand, results yielded with bibliometrics are similar to those of a systematic literature review and of a metaanalysis, but the explicative power is by far higher. Compared to a systematic literature review, bibliometric methods are able to analyse a wider range of contents without having to limit the physiological number of studies taken into consideration or to compromise on the rigor of the protocol. These methods "can analyse any type of study as long as connections among studies exist in the corpus of analysed studies" (Zupic and Čater 2015). Yet, all the benefits of a meta-analysis are maintained too, but without the need to compensate/focus on a reduced number of investigated relationships. As a matter of fact, bibliometric methodologies can assess hundreds or even thousands of studies and map a research field, and its main topics/relationships inquired in a graphic way that is easy to understand (Caputo et al. 2018; Marzi et al. 2017).

The data collection process started with a query on Elsevier's Scopus. Considering the fact that Sport Entrepreneurship is an emergent field of study, our methodological choice to use Scopus instead of Web of Science Core Collection has been guided by the necessity to be as inclusive as possible (Aghaei Chadegani et al. 2013). Consequently, we entered the following searching strings in Scopus: "sport*" together with the term "entrepreneur*" in titles, abstracts and keywords (operator "TITLE-ABS-KEY" in Scopus' advanced research tab). The selected query results as the most inclusive one. Indeed, the scope of this paper is to map the structure of a whole field of research, 
meaning that there is a need to gather the highest number of papers possible. Coherently, we used 'starred' terms so to extract any paper that in the title, abstract, or keywords would include all derivations of the core concept. The term "sport*" captures a corollary of terms such as sport-related, sportsman, sportsmen, sportswoman, sportswomen, sportsmanship etc.; the term "entrepreneur*" includes a series of expressions such as entrepreneurship, entrepreneurial, and entrepreneur-alike. As a result, the final query was:

\section{TITLE-ABS-KEY (sport*AND entrepreneur*)}

The research was limited to "articles" and "literature reviews", within the field of "Business, Management and Accounting". The considered timespan is between 1988 and 2018, thus we focused on the last 30 years of research on the topic (Marzi et al. 2017, 2018). The initial dataset was composed by 144 papers. After a manual analysis of all papers by each of the authors, some papers not related to the field under study were removed. Similarly, the authors included in the dataset only considered Ratten's (2010) definition of sport entrepreneurship. Thus, the final dataset resulted in 86 papers. Moreover, in order to ensure the inclusion of all relevant data, a cross-validation was made both with EBSCO Business Source Premier and Thomson Reuters Web of Science. In this perspective, no other significant papers was found. The data has been gathered on the 14th January 2019.

Specifically, in relation to the similarity analysis, VOSviewer 1.6.7 was used as bibliometric tool/software for both the coupling analysis and for the aggregation of data. We included all 86 papers in VOS, however, only 69 showed connections in terms of shared references, indicating that 17 papers out of these 86 are completely built on different theoretical foundations, while dealing anyway with the same topic. Consequently, our analysis could only include 69 of the inter-connected papers in its representation.

Regarding the results in VOSviewer, they are created through a co-occurrence matrix; Co-occurrences rise from the presence, occurrence, and betweenness of analogous pairs of terms in the data, in our case of cited references. VOS completes a set of interated routines to build a comprehensive map in which the items are spatially located in relation to the distance between any pair of items, and in our case, this distance reflects pairs' similarity in term of cited references.

After this step, a cluster analysis is performed with additional mathematical routines. Clusters are determined in base of the item shared references - pairing items with the highest level of it. Once the clustering process is completed, to each cluster, and thus to each of its items, a colour is associated (van Eck and Waltman 2010).

In a sectoral map, in relation to the cluster distribution, the distance between items has to be understood as an indication of the relatedness of the items, either if the comparison is done within or between cluster elements. Thus, the smaller the distance, the stronger the relatedness in terms of citations used (van Eck and Waltman 2010). In addition, the cluster analysis highlights the diversity in terms of knowledge bases of the several aggregates. Thus, the groups of items within a cluster are strongly linked together in terms of co-citations. This also indicates that if an item belongs to a cluster, it is part of a specific stream of research or refers to a particular topic (For a detailed 
mathematical explanation about VOS technique and VOSviewer, please see van Eck and Waltman 2009).

\section{Results of the bibliometric activity indicators}

In this section we present results from a series of bibliometric activity indicators showing: i) the distribution of the papers among the years (Fig. 1), ii) the most cited papers (Table 1), iii) the most prolific authors (Table 2), iv) and the most prolific countries (Table 3 ) in term of number of papers related to sport entrepreneurship.

As Fig. 1 clearly shows, starting from 2010, an increased interest in sport entrepreneurship as field of study has been identified. In particular, periods from 2010 to 2012 and after 2015, seem to be the most prolific for the field. This trend is also confirmed in the following table (Table 1).

As displayed in Table 1, the majority of highly impactful (or most cited) papers have been published from 2010. In particular, following the high number of citations and the relevance of studies, we can assume that the two papers published by Vanessa Ratten "Developing a theory of sport-based entrepreneurship" (Ratten 2010) and "Sportbased entrepreneurship: Towards a new theory of entrepreneurship and sport management" (Ratten 2011b) are two seminal and fundamental papers for the field of study.

Similar conclusions can be drawn from the analysis of most prolific authors in sport entrepreneurship (Table 2). Again, Vanessa Ratten from La Trobe University in Melbourne (Australia), is the most prolific and cited author in this field. She is followed by Paul Jones from Coventry University in Coventry, United Kingdom. On the third step of a hypothetical podium, we can find Per Svensson from Louisiana State University in Los Angeles (US). In general, the rest of the authors have no more than two papers each, but with such a limited set they still collect high amounts of citations.

Finally, regarding the most prolific countries (Table 3), we can find United States, followed by Australia, and United Kingdom both in terms of number of documents and citations. Please note that if a paper has more than one author, the number of citations has been summed for each author and country. For example, if a paper with 10 citations

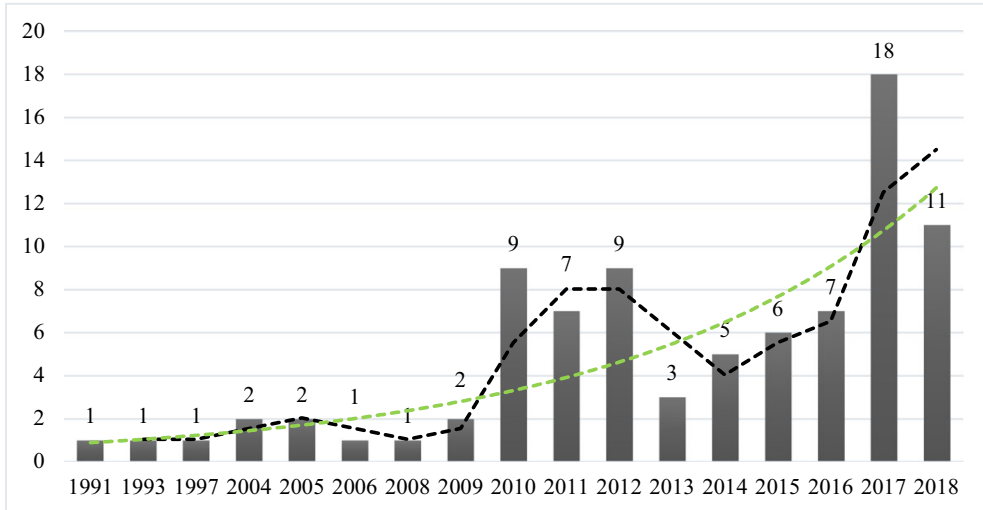

Fig. 1 Papers distribution by years 


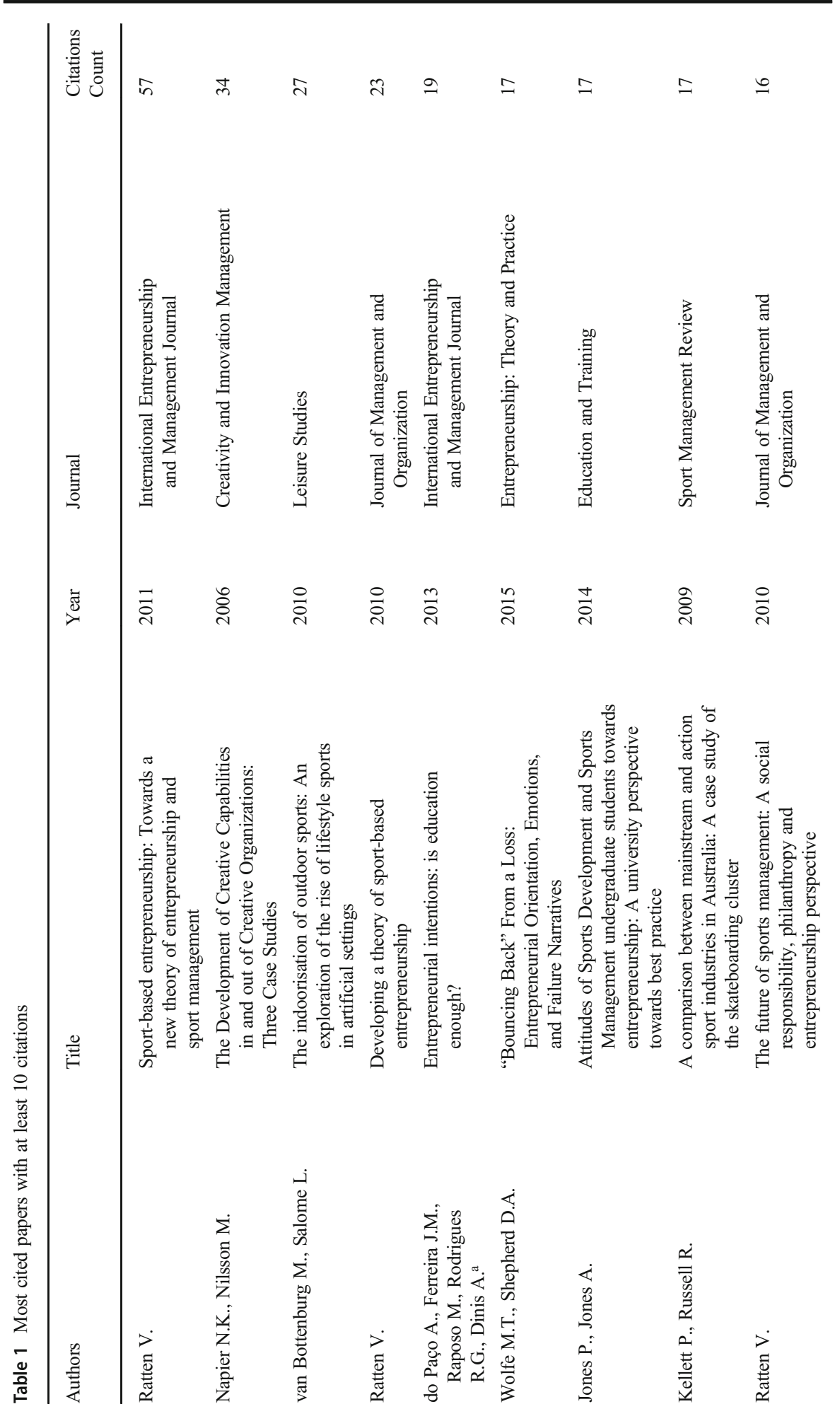




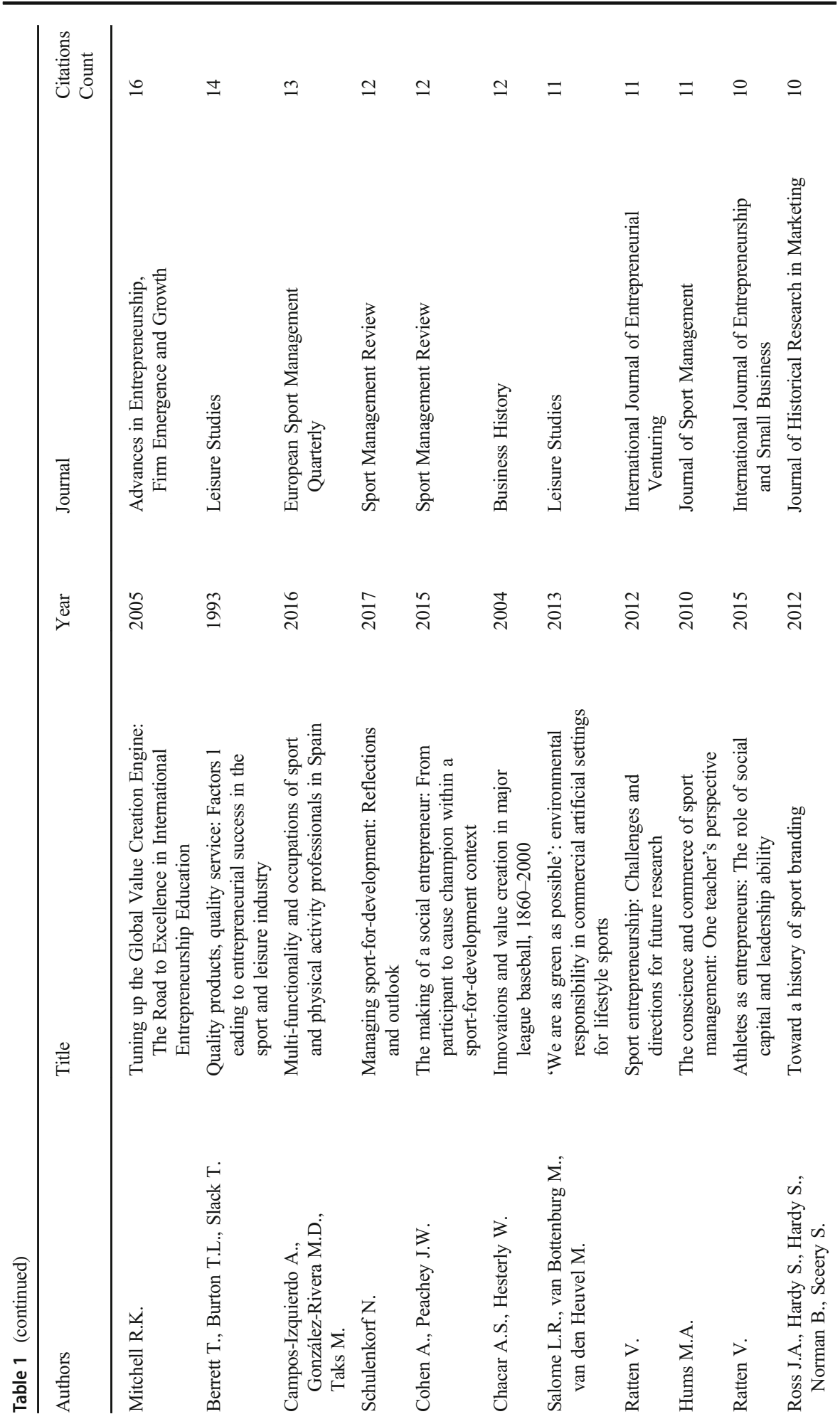




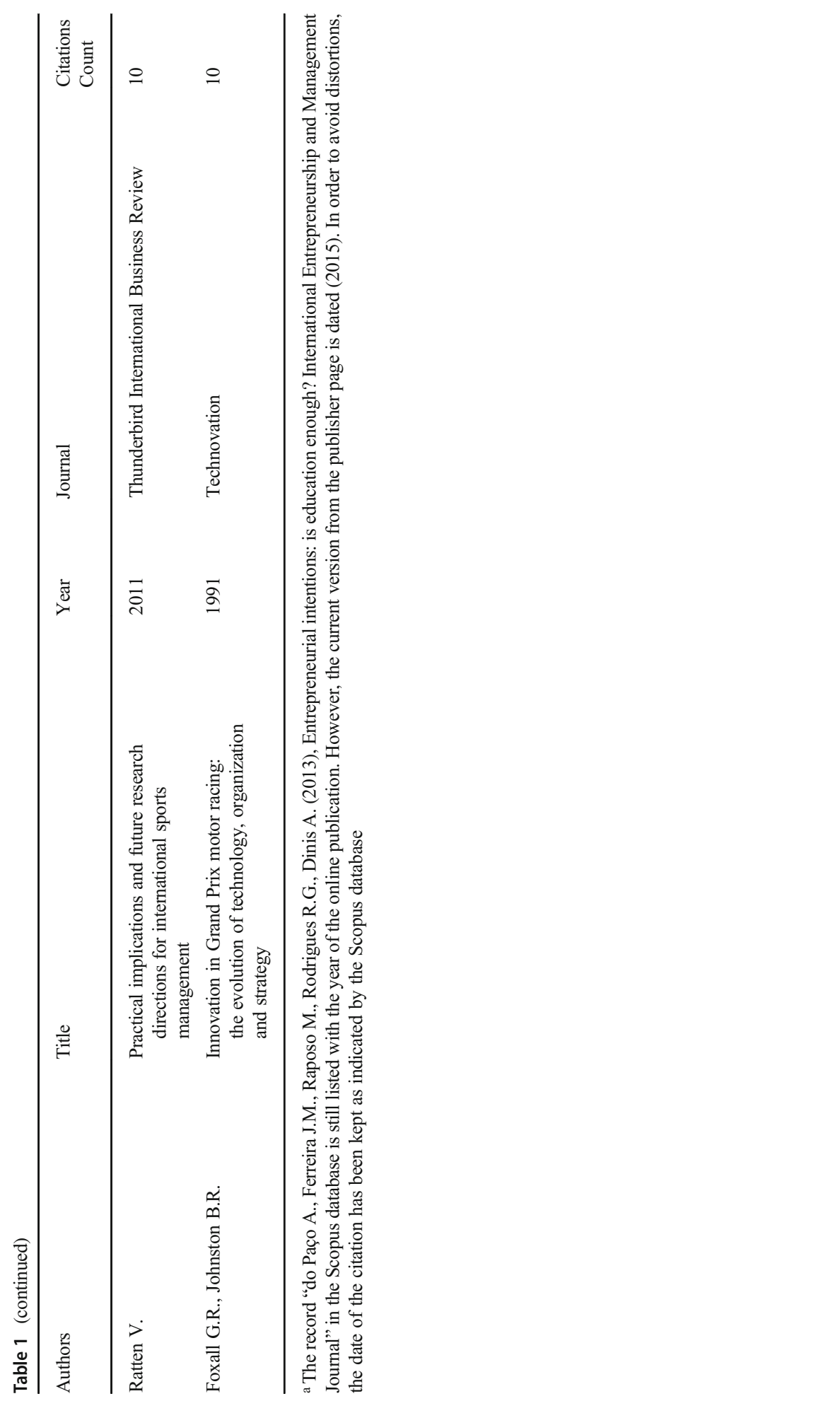


Table 2 Most productive authors with at least 2 documents

\begin{tabular}{lll}
\hline Author & Number of Documents & Citations \\
\hline Ratten V. & 16 & 163 \\
Jones P. & 3 & 21 \\
Svensson P.G. & 3 & 5 \\
Van Bottenburg M. & 2 & 38 \\
Jones A. & 2 & 20 \\
Peachey J.W. & 2 & 15 \\
Crespo Hervás J. & 2 & 9 \\
Terjesen S. & 2 & 6 \\
Moreno F.C. & 2 & 4 \\
Valantine I. & 2 & 4 \\
González-Serrano M.H. & 2 & 2 \\
Pérez-Campos C. & 2 & 2 \\
\hline
\end{tabular}

has one author from Australia and one author from United Kingdom, both countries received a score of 10 in this table.

\section{Results of the VOS analysis and the systematic literature review}

In the present section, following recent research using both bibliometric and systematic literature review methods (Caputo et al. 2018; Fernandez et al. 2015; Sassetti et al. 2018) we present the results of the systematic literature review. We based our discussion on the ten most cited papers belonging to each cluster obtained by the VOS analysis via bibliographic coupling (Fig. 2).

Table 3 Most productive countries with at least 2 documents

\begin{tabular}{lll}
\hline Country & Documents & Citations \\
\hline United states & 27 & 243 \\
Australia & 15 & 92 \\
United Kingdom & 15 & 75 \\
Canada & 8 & 44 \\
Spain & 7 & 27 \\
Sweden & 4 & 43 \\
Portugal & 4 & 27 \\
Lithuania & 3 & 4 \\
Norway & 3 & 3 \\
Netherlands & 2 & 38 \\
New Zealand & 2 & 4 \\
Iran & 2 & 0 \\
\hline
\end{tabular}




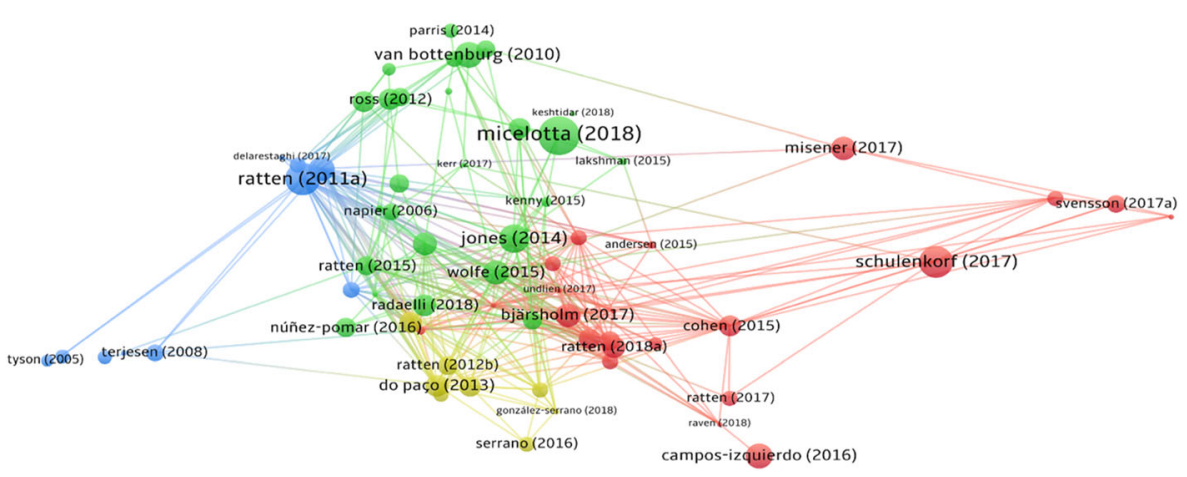

Fig. 2 Results of the VOS Analysis

The following table (Table 4) presents a brief of the results of our interpretation of the four clusters emerged through the VOS analysis. The first one (Cluster 1 - Green) is central and related to sport entrepreneurship theory and factors triggering sportspeople's entrepreneurial intention and orientation. The second (Cluster 2 - Blue) concerns the environmental factors and conditions fostering sport entrepreneurship, while the third (Cluster 3 - Yellow) is related to sport entrepreneurial education. Finally, the last cluster (Cluster 4 - Red) deals with the social role of sport entrepreneurship and its implications.

\section{Cluster 1 - green: Sport entrepreneurship theory and factors triggering sportspeople entrepreneurial propensity}

In general, this cluster aggregates papers that have over the years provided theoretical and empirical validation of sport entrepreneurship theory and factors triggering sportspeople entrepreneurial propensity (e.g., Ratten 2015). Coherently, entrepreneurial dynamics in the sport industry are central elements of these contributions. As such, the studies in this cluster subdivide themselves according to two different points of view. On the one hand, we have studies that investigate the sport industry as a context for theoretical research around entrepreneurship (e.g., Napier and Nilsson 2006; NúñezPomar et al. 2016; van Bottenburg and Salome 2010; Wolfe and Shepherd 2015). Conversely, contributions examine the entrepreneurial propensity of professional athletes and sportspeople (e.g., Jones et al. 2017; Kenny 2015; Micelotta et al. 2018). For

Table 4 Schematic representation of the clusters forming the sport entrepreneurship field of research

\begin{tabular}{|c|c|c|}
\hline \multicolumn{2}{|c|}{$\begin{array}{c}\text { Cluster } 1 \text { - Green: Sport Entrepreneurship Theory and Factors Triggering Sportspeople Entrepreneurial } \\
\text { Propensity } \\
28 \text { papers - 220 citations }\end{array}$} \\
\hline $\begin{array}{c}\text { Cluster 2 - Blue: Environmental Factors } \\
\text { and Conditions Fostering Sport } \\
\text { Entrepreneurship }\end{array}$ & $\begin{array}{c}\text { Cluster } \mathbf{3} \text { - Yellow: Sport } \\
\text { Entrepreneurial Education }\end{array}$ & $\begin{array}{c}\text { Cluster } \mathbf{4} \text { - Red: Social Role of Sport } \\
\text { Entrepreneurship and Its } \\
\text { Implications }\end{array}$ \\
$\begin{array}{c}10 \text { papers - } 115 \text { citations } \\
9 \text { papers - } 56 \text { citations }\end{array}$ & 22 papers - 81 citations \\
\hline
\end{tabular}


these reasons, this cluster has a central position in the VOS Viewer map and often provides theoretical bases for the studies in the other clusters, which instead investigate specific aspects of sport entrepreneurship. Therefore, we decided to label this cluster as "Sport Entrepreneurship Theory and Factors Triggering Sportspeople Entrepreneurial Propensity".

The most cited paper of this cluster is the one of Napier and Nilsson (2006), which somehow offered one of the first associations between sport and entrepreneurship. Grounded in the Resource Based View of the firm (Penrose 1959) and the dynamic capabilities of literature (Eisenhardt and Martin 2000), the paper investigates the case study of an American Football team, among the others. In particular, it shows how creative entrepreneurs build collaborations, exploit knowledge, and enhance intra- and extra-organizational relationships. As the authors wrote, "the football-team approach involves building up resources through planning and execution of the process of development (through which the team and coaches develop building blocks, culture, and interaction patterns). As part of the process, the coach sets the 'parameters', such as how flexible a football team needs to be for creativity to emerge. With that accomplished, he focuses on deploying those resources for 'creative moments' during the games. The ability and trust to do so stem from achieving results/wins and subsequent confidence and respect from stakeholders, including players" (Napier and Nilsson 2006, p. 276). Although this paper was not deliberately investigating sport entrepreneurship, it can be considered as one of the main sources that provided an anchor for future scholars to justify the potential of sport sector as an entrepreneurial one.

For example, Wolfe and Shepherd (2015), exploring entrepreneurial orientations, emotions, and failure, stated how collegiate football programmes can be seen as entrepreneurial organizations. The authors found how narratives about entrepreneurial orientation (EO), and negative emotional content, has a U-shaped relationship with subsequent (i.e., next game) performance. At the same time, positive emotional content exhibited an inverse U-shaped relationship with subsequent performance. In a similar vein, Núñez-Pomar et al. (2016), using a fuzzy-set qualitative comparative analysis of Spanish Sport companies, showed that EO is a sufficient condition for a successful performance in small service companies. However, the same is not true for large ones. In particular, the study shows that the model 'innovation + proactiveness + risk-taking' works well in small businesses in the sports service sector as a sufficient condition for performance.

Other studies belonging to the same stream show how entrepreneurs seize opportunities in the sport industry. Evidences from Kellett and Russell (2009) showed how entrepreneurs benefited from seizing the opportunity provided by the action sport industry (e.g. freestyle snowboarding, alpine skiing, motocross, surf), which evolved in a chaotic and unregulated fashion. Moreover, van Bottenburg and Salome (van Bottenburg and Salome 2010), investigating the indoor sport market, showed how the entrepreneurial initiatives "were taken by internationally-oriented entrepreneurs who can be regarded as outsiders to the mainstream sports world" (p.146). The paper highlights the rise of indoor lifestyle sports and discusses the conditions under which entrepreneurs in the Netherlands have created the indoor market. The paper shows that the rise of this economic market cannot be understood if it is solely interpreted as the result of economic, technological or natural developments, but also by recognising how the structures and cultures pervaded the rise of this new market. 
Vanessa Ratten seems to be among the most prolific and active scholars in the field of sport entrepreneurship, and in several of her papers, she contributed to the definition of the field. "Sports entrepreneurship can be described as the mindset of people or organisations actively engaged in the pursuit of new opportunities in the sports-context. Sports entrepreneurship refers to any innovative activity in a sports context where most activities are enhanced with a proactive and risk-taking quality. The essence of sport entrepreneurship is that entrepreneurial activities are embedded almost invisibly into most sports organisations" (Ratten 2012b, p. 66). A few years later, the same scholar provided a theoretical and conceptual understanding of athletes as entrepreneurs by utilising human capital in the form of social, emotional, and leadership abilities (Ratten 2015). The paper highlighted how athletes as entrepreneurs are partly determined by their human capital and individual attributes and those affect the business success. This means that both on- and off-field abilities of an athlete shape how human capital is developed. In fact, it was hypothesized how sportspeople are characterized by a higher locus of control, situational control, need for achievement, resilience, and discipline than the average person. All traits are related to higher entrepreneurial orientation and intentions.

Other studies have contributed to such investigation of the characteristics of athlete entrepreneurs. For example, Kenny (2015), studied the learning needs for entrepreneurial skills of professional athletes for a career transition. Indeed, this paper deals with the issues faced by athletes, who cannot maintain their sport career at a professional and competitive level forever. For this reason, most of professional athletes may need to transit towards a different career, either by obtaining a more managerial role in sport and related industries, or by moving to a completely new industry. In both cases, the athlete is faced with entrepreneurial challenges. Studying professional rugby players, the author provided evidence of the existence of entrepreneurial learning needs to be considered when designing an entrepreneurship programme dedicated to athletes.

Then, this study corroborates previous research on the benefits of sports for entrepreneurs. In a similar vein, Jones and Jones (2014) investigated how students of sports development and management are typically more entrepreneurial by nature. This is due to their prior experience in coaching and training within their respective sports disciplines. Jones and Jones (2014) reinforced the importance of entrepreneurship education to non-business disciplines, because an entrepreneurial career is highly complementary to the skills achieved in a sports career. In fact, such careers require a high proportion of self-employment, while the paper clearly shows that Sports Development and Sports Management students were typically enterprising by nature. Moreover, the majority of students indicated that they were attracted to a future entrepreneurial career in a sports-related discipline and were characterised by their mature attitudes towards their career development and future inclination regarding an entrepreneurial career choice.

Moreover, Jones et al. (2017) explored the entrepreneurial experiences of sport coaches/instructors. The results showed how sports coach/instructors exhibit several novel behaviours including pro-social (entrepreneurial) behaviours. Furthermore, and interestingly, the authors reported how sports coaches/instructors typically work in lifestyle businesses thus they do not actively seek growth. Even this paper argues for the need of a specific training provision to enhance operational processes in the sport industry. 
Finally, Micelotta et al. (2018) investigated women's leagues in the sport industry to study how the industry gender imprinting, which the authors define as the persistence of cultural values, beliefs, norms, and orientations associated with masculinity or femininity, and how it influences new ventures. In this study, the authors revealed how gender imprinting negatively affects the new ventures of women in a male-dominated industry, through three liabilities: identity, conformity, and differentiation. This study, thus, addresses the challenges that new ventures face when they do not align with the industry imprint.

\section{Cluster II- blue: Environmental factors and external conditions fostering sport entrepreneurship}

Sport entrepreneurship is a "emerging form of entrepreneurship is usually inherent in the management of sports, which transforms sport-based organisations into an entrepreneur and enterprise" (Ratten 2011b, p. 314). As stressed through the previous paragraph, it usually derives from someone's passion for a sport in conjunction with high EO. Indeed, sport entrepreneurial ventures are sometimes subsided by local or national governments. This occurs by either providing entertainment to a community, or fostering the development of the culture or civil citizenship through the practising of a specific sport (Ratten 2010). Otherwise, the existence of an elevated number of passionate people or practicing a certain sport in a specific area may incentivise new entrepreneurs to start sport entrepreneurial ventures. This is due to the fact that these ventures may count on a possible unsatisfied demand for certain goods necessary to practice the sport or the need for sport venues (Ratten 2011b). Sport entrepreneurship is, as a matter of fact, a social phenomenon, and it cannot be detached from the context that triggered its emergence (Ratten 2011a).

Here, it emerges the importance of environmental and contextual factors fostering sport entrepreneurship, which is the prevalent topic of papers belonging to the second cluster.

For example, Briedenhann (2011), inquires the potential relationship between sport mega-events and sport entrepreneurship. The author specifically considered the case of the 2010 FIFA World Cup in South Africa. The author employed a survey-based method to assess the effect of such an event. Results show that local hosting communities evaluated positively the potential entrepreneurial opportunities deriving from the World Cup. However, they were also sceptical of the government's uncontrolled expenses to finance the event.

These findings are coherent with Tyson et al. (2005), Terjesen (2008) and Devine et al. (2010) research studies. In particular, Tyson et al. (2005), observed how the 2005 Cricket World Cup was a catalyst for tourism and micro-enterprises development in Trinidad and Tobago. Thanks to 82 interviews with the event managers, the authors observed how the number of tourists visiting the country increased exponentially, with evident benefits in terms of employment. However, also sport-related entrepreneurial ventures increased their numbers. As a matter of fact, more people started to practice sport after the event, thus increasing the need for providers of such goods and services to practice sport.

Devine et al. (2010), in a similar fashion, focused on the impact of Ironman Triathlon Events on hosting communities. The findings of this research stressed out two important phenomena. First of all, sport events may attract a significant number of tourists in a specific destination. Thus, it may generate extra revenues for entrepreneurs 
involved in tourism. Additionally, it may generate extra revenues for entrepreneurs involved in the sport industry. Indeed, attending sportspeople may need to train or to purchase new items.

Terjesen (2008) observed how the International Association of Ultrarunning World Cup $100 \mathrm{Km}$ in South Korea triggered the diffusion of this discipline and of 'ultrarunning-related' ventures in South Korea. Indeed, this study observed how the success of the event facilitated people to establish training ventures, gyms, and shops to help new ultra-running fans in starting the practice of the sport. This may be also related to ultra-running values, which are quite compatible with Korean cultural values, i.e. resistance, perseverance, and camaraderie.

Nevertheless, sport events are not the only external conditions capable of fostering the emergence and success of sport entrepreneurial ventures. Indeed, Toffoletti and Thorpe (2018) focused on the importance on the ability of sport celebrities in fostering customers' awareness towards a specific sport practice. Consequently, sport celebrities can turn into entrepreneurs by promoting their own products or services thanks to internet platforms such as social media (Rialti et al. 2018).

Finally, Franco and Pessoa (2014) observed how partnerships in the university sport sector may resemble a form of collaborative entrepreneurship. In fact, thanks to such a kind of partnerships different institutions may generate social value. Additionally, it emerged how universities may play a role in educating people practicing sport about how to reap sport-related opportunities.

\section{Cluster III - yellow: Sport entrepreneurial education}

Education has been deemed fundamental to increase individuals' orientation to became an entrepreneur and their intention toward starting an entrepreneurial venture (e.g. Rialti et al. 2017). Accordingly, education is considered instrumental to foster students' autonomy, self-confidence, opportunities exploration, and exploitation capacity - all while making them more aware about potential career paths (Fayolle et al. 2010). In this perspective, sport entrepreneurship stream is not representing an exception. Henceforth, the third cluster that emerged from our bibliometric analysis contains papers dealing with sport entrepreneurial education. In detail, a part of the papers included in this cluster deals with the analysis of entrepreneurial intention and orientation of students enrolled in sport courses using entrepreneurship theory as a theoretical lens. The other papers deal with analyses of the cause of this phenomenon (i.e. why people practicing sport have higher entrepreneurial intention, orientation, and capabilities) by building on sport courses students characteristics.

To what concerns the first half, it includes the most cited paper from this cluster, the one written by do Franco and Pessoa (2014) entitled "Entrepreneurial intentions: is education enough?". This research tried to identify who between male students enrolled in sport schools and girls enrolled in business schools show higher entrepreneurial orientation or intention. The research built on the widely known Ajzen's (1991) Theory of Planned Behaviour (TPB), which in the entrepreneurship context assumes that a person's psychological attributes (locus of control, need for achievement, propensity to risk, self-confidence, and tolerance to ambiguity) may influence entrepreneurial orientation and intention. The authors collected data through a survey, and performed a t-test and a Levene's test to evaluate which typology of student was more 
inclined to become an entrepreneur. Interestingly, sport school's students showed higher entrepreneurial orientation, thus supporting the hypothesis that people interested in sport are characterized by high propensity toward entrepreneurship. Such a perspective is also explored in Teixeira and Forte's (2017) paper. Specifically, the authors compared entrepreneurial intentions of 2434 students enrolled in 32 different academic courses. Results show how students attending courses not involving any kind of entrepreneurial education are the ones characterized by higher entrepreneurial intention and the most likely to start their own venture. In detail, students enrolled in sportrelated courses are the ones showing higher entrepreneurial intentions. This phenomenon calls for a higher levels of attention to be paid to these academic courses, since interpersonal relations management, teamwork, and faster decision-making capabilities are shown by people who practice sports. Among the conclusions, the authors pointed out how best practices coming from sport courses may also be used in a purely entrepreneurial sense. In line with do Paço et al. (2013), also Gonzalez Serrano et al. (2016) focused on a comparative analysis based on a student sample using the TPB. Building on extant findings related to higher entrepreneurial orientation showed by students enrolled in sport courses, this paper focused on the eventual existence of gender differences between male and female students in terms of entrepreneurial intention. Strangely, no difference related to gender was detected, thus the authors inferred that there is no specific need to tailor sport-based courses according to students' gender to increase their entrepreneurial orientation. This initial research was then extended via two successive researches again from González-Serrano et al. (2017, 2018). The first one deals with the exploration of the relationship between entrepreneurial intentions and capabilities of students enrolled in sport courses, observing how education may influence students' innovation, creativity, and willingness to start a business. The second one is instead a comparative analysis between the Spanish and Lithuanian contexts. Results of the statistical analysis based on PLS-MP algorithms show how Lithuanian sport courses' students are characterized by higher entrepreneurial intentions. Yet, in the Spanish context, the entrepreneurial intention derives from students' personal attitude, while in the Lithuanian one, this derives from other factors such as the simplicity of starting a venture.

The other half of the cluster instead contains papers dealing with the exploration of the causes of this phenomenon, concerning and adopting perspectives not exclusively depended to classical entrepreneurship models and theories. Mitchell (2005), indeed, explored how cognitive characteristics usually necessary for a person to succeed in sport may be fundamental even to succeed in an entrepreneurial endeavour. A model was consequently developed by the author, pointing out how any successful entrepreneurial education program should be built on best practices coming from sport education. Thus, the paper identified the need to develop some sort of sport-based entrepreneurial education. Such a program may in fact be capable to foster entrepreneurs' memory, problem solving capacity, speed of processing information, and learning rate. Similar results were also stressed out by Neergaard and Krueger (2008). Accordingly, "competitive sports cultivate the aptitude to constantly better oneself and aim for becoming the best" (Neergaard and Krueger 2008, p. 19). Students who practiced sport as young children usually grow-up in competitive social contexts capable of generating the skills necessary for entrepreneurship (Stambaugh and Mitchell 2018). 
Moving from that, suggestions concerning how to develop specific entrepreneurial education programs for sport practitioners were developed. Ratten's (2012b) editorial, in this vein, stresses the importance of developing education programs for sport entrepreneurs. Sport-related entrepreneurial ventures contribute significantly to the economic system of any country. Thus, there is a need to educate sport entrepreneurs, which are usually characterized by an elevated level of propensity toward starting a venture. Yet, they may anyhow lack technical skills required to manage a company. Heavy assistance from institutions and policy-makers is thereby necessary. Indeed, sport entrepreneurs may need assistance related to getting grants and developing ad hoc financial structure.

\section{Cluster IV - red: Social role of sport entrepreneurship and its implications}

Entrepreneurship may create new jobs, stimulate economic growth, and be associated with the generation and commercialization of new relevant innovations. Also, the social role of entrepreneurship is evident. In fact, the existence of entrepreneurial ventures within a specific geographical area may be related to new social benefits for the community living around the business. This occurrence is true both in the case of for-profit and social entrepreneurial ventures. Specifically, in the first case, sometimes spill-overs of ventures' activities may cause benefits to the community in the form of renewed infrastructures or new attention from policy makers to that area. In the case of social entrepreneurial ventures, instead, they will directly create value with their activities capable of generating benefits for communities - i.e. in the form of free services to inhabitants of a specific area (Zollo et al. 2018).

Accordingly, sport entrepreneurship may have an extremely relevant social impact. Sport entrepreneurs may indeed generate social value by the creation of social activities that may be instrumental for participants to practice sport activities for their health, overcoming isolation, and giving them hope to improve their life conditions (Bjärsholm 2017). Such a topic is the one of characterizing the fourth and final cluster, which has consequently been named the "Social Role of Sport Entrepreneurship".

Schulenkorf (2017), in this vein, reviewed existing literature belonging to the sport-for-development (SFD) field of literature. Generically, the expression SFD has been used to describe the intentional "use of sport to exert a positive influence on public health, the socialisation of children, youths and adults, the social inclusion of the disadvantaged, the economic development of regions and states, and on fostering intercultural exchange and conflict resolution" (Lyras and Welty Peachey 2011, p. 311). As it is possible to understand, sport entrepreneurial ventures have a huge role in the success of SFD initiative, such ventures are in fact the ones usually contacted by institutions to implement SFD. Here, the social value that may be created by sport related entrepreneurial ventures begins to emerge. Sport related entrepreneurial ventures participating to SFD initiatives are in fact important players in fostering aggregation between members of a community thanks to social activities; in particular, in the case of social activities targeting disadvantaged people.

A similar perspective is also shared by Cohen and Peachey (2015). The authors, indeed, focused too on SFD initiatives. In detail, they used a narrative 
inquiry approach to analyse a well-known SFD case, the Street Soccer USA. Findings show how the involvement of sportspeople into SFD may make them a sort of social entrepreneurship champions. Yet, sportspeople may be more motivated to participate to initiatives (and also more capable of engaging participants into sport trials) whether their backgrounds contain either sport or life traumatic experiences.

Hemme et al. (2017), instead, tried to define the boundaries of sport entrepreneurship's social role through a phenomenological inquiry based on interviews with managers and employees of sport related entrepreneurial ventures (in this case gyms). Results showed how sport entrepreneurs are 'effectively' fully fledged entrepreneurs. Yet, they also have a social role as the most of them consider the physical and mental wellness of customers among the highest priorities of their business. This is consistent with typical two scopes of social entrepreneurs, namely the social change and personal development of customers' lives.

To also target social objectives, anyway, traditional organizational structures may not be a suitable solution to follow. For-profit entrepreneurial ventures are indeed frequently organized in order to maximise revenues and to obtain profits without regarding social value. Instead, ventures aiming at creating social value need to be organized following different organizational schemata. In this perspective, it has been observed how entrepreneurial ventures aiming at social value creation are frequently hybrid organizations, which are characterized by a business unit dealing with for-profit activities and one dealing with not-for-profit, or social activities (Misener and Misener 2017).

Svensson and Seifried (2017), coherently, explored how the hybrid organizational structure is extremely recommended in ventures involved in Sport for Development and Peace (SDP) activities. SPD activities are sport centred activities aiming to create social value by preventing conflicts thanks to the involvement of people living in conflictual area in sport. Usually, SPD activities' main objective is to prevent children from becoming soldiers by educating them in sport and other disciplines. SPD activities are usually arranged by mostly social entrepreneurial venture not looking after profits; yet, as such ventures need funding to continue their operation, the possibility to have 'a sort' of for-profit branch collecting resources to finance activities may represent the best way to survive in the long term.

Indeed, in a different research, Svensson (2017) argued how adopting a hybrid structure may allow social entrepreneurial ventures involved in SPD activities to address the divergent logics putting pressures on them. In fact, hybrid structures may be extremely helpful whether certain stakeholders are interested in economic sustainability while others are interested exclusively in social value creation.

Finally, concerning the last papers included in the analysis of this cluster, we observe how several authors pointed out the importance of social value of sport for sport marketing strategies.

As a matter of fact, Ratten $(2016,2017)$ highlighted the importance for marketers to consider how much customers (and fans) take into account the social value they can get from attending sport events or from participating to sport-related activities. Henceforth, marketing strategies should make potential attendants aware of that. Such a view is also present in the paper written by Crick and Crick (2016). 


\section{Discussion of the systematic literature review and gaps for future research}

The findings from the literature review highlighted several relevant insights about sport entrepreneurship and its sub-streams of research. In detail, we can find four main trends in the literature: 1) the study of internal factors that favour sport entrepreneurship, e.g. how practicing or having practiced a sport may be related with the willingness to create a new venture (Jones and Jones 2014); 2) the study of external factors that may favour or hinder sport entrepreneurship e.g. sport events that may 'spark' new entrepreneurial opportunities (Terjesen 2008); 3) The study of the role of education and specifically entrepreneurial education on the entrepreneurial venturing process, e.g. the ability of sport course to improve entrepreneurial intention (González-Serrano et al. 2017); and finally, 4) why sport entrepreneurial ventures have a social and societal impacts, e.g. the contribution of sport to public health and children personal development (Lyras and Welty Peachey 2011).

In relation to the first sub-stream, on the one hand, emerged that professional sportspeople are extremely prone to become entrepreneurs either during their sport career or after retirement (Jones and Jones 2014). Professional athletes, in fact, need discipline and rigor to be able to endure stress, and be resilient to practice sport successfully. Yet, sportspeople usually also have higher locus of control, situational control, and awareness of their real possibilities than the average person (Ratten 2015). To succeed in sport, anyone needs in effect to be fully in control of their own body and mind to achieve a successful athletic performance (Kenny 2015). The same applies to situational control. In fact, each sport venue is different, and the opportunity to be aware of the situation may generate different kinds of advantages. As an example, just think of professional skiers; all slopes are different, thus, awareness of advantages obtainable due the slope characteristics may make all the difference between success and failure. Finally, the requisites developed through the sport training, such as rigor, discipline, and endurance to bear fatigue, may allow sportspeople to develop the same qualities in off-of-the-field situations (Jones et al. 2017). For managing a venture to strictly respect obligations, project deadlines, or payments, due dates are similarly important.

In addition, like traditional entrepreneurs are bounded by passion for their job, sportspeople are commonly passionate towards the sport that they practice. Thereby, it emerges why sportspeople may wish to start a venture at the end of their professional career to continue to be involved in something they are passionate about (Ranfagni and Runfola 2018).

Probably, for all these reasons, sportspeople may have higher entrepreneurial intention and orientation than average.

Moving from these preliminary findings, it is possible to attempt to outline of the characteristics of sport entrepreneurs; such characteristics have proven to be fundamental in building the following framework and to develop managerial implications. In detail, then, sport entrepreneurs are (a) persons often highly engaged with a sport (Ranfagni and Runfola 2018), (b) that desire to turn their passion or former profession into a new career (Ratten and Jones 2018), (c) characterized by an entrepreneurial mind-set and thus more capable than the average person to identify and seize opportunities emerging in the environment (Ratten and Miragaia 2019), (d) and interested in 
motivating other people in starting to practice a sport discipline (Wicker et al. 2009). In this perspective, no distinction has been made in respect of former professional athletes and 'nascent' forms of sport entrepreneurs such as personal trainers or professional coaches. In fact, both these figures show expertise in the sport, expertise in the industry, and willingness to operate as entrepreneurs in sport industry. In the same way, we tried to encompass this definition both self-employed professionals and people managing owned sport ventures as both are in their way entrepreneurs.

This sub-stream, although containing several prominent contributions, still needs to better explore which personal characteristics related to the practice of a sport are connected with a higher entrepreneurial orientation. In this vein, several psychometric studies explored the connection between the personality characteristic and sport/life success (Newcombe and Boyle 1995; Raglin 2001; Ross et al. 2003). Management scholars are therefore invited to further investigate which characteristics relate to entrepreneurial orientation and success by developing a series of measurement instruments. Yet as premised, sport entrepreneurs while having mostly similar characteristics, exercise their role in several occupational professions, e.g. proper founders of a sport club or fitness centres (Hemme et al. 2017), self-employed coaches (Jones et al. 2017), ex-athletes now involved in managing or promoting their passion as lifestyle entrepreneurs (Ratten and Miragaia 2019). Scholar have still a lot to say about the possible effect of such diversity; for example, is there a difference that affects entrepreneurial intentions across these professions? does this difference affect their entrepreneurial orientation? Is the potential of sportspeople being entrepreneurial 'unleashed' similarly or are the trigger mechanisms different? Indeed, becoming a sport entrepreneur at a later stage in life (Hennekam 2015; Kautonen et al. 2017), as in the case of ex-athletes after their retirement from an agonistic sport career, may show different paths from starting a self-employed job (Jones and Jones 2014) or being a manager in a league (Micelotta et al. 2018).

Also, entrepreneurship scholars already explored the role of passion in entrepreneurship, showing that it is a critical success factor for any entrepreneurial venture (Cardon et al. 2005). In Cardon et al. (2009) own words, passion is "consciously accessible, intense positive feelings experienced by engagement in entrepreneurial activities associated with roles that are meaningful and salient to the self-identity of the entrepreneur" (p. 517). However, while for sportspeople the passion towards a sport activity is pretty straight forward (Kenny 2015), the same may not be said to relate themselves to an entrepreneurial activity, although still related to the same sport. For example, Gartner et al. (1999), propose three identities in which entrepreneurs selfrecognise themselves; an inventor identity, where the individual passion is devoted to innovation and identification of new opportunity; a founder identity, with a passion and enjoyment related to establishing a new venture to exploit opportunities; and, finally, a developer identity, for which an entrepreneur is passionate to the nurture and growth of her/his 'creation'. Scholars are therefore invited to investigate 'if' and 'to what extent' passion toward sport is a catalyst of individual sportspeople's willingness to start an entrepreneurial venture and what are the similarities and differences between entrepreneurship in sport and entrepreneurship in other contexts.

Siding the internal elements, which may trigger sport entrepreneurship, external factors may also play a role. This second sub-stream clearly shows how environmental factors may influence the willingness of sportspeople to start a venture. First, the 
existence of venues and of a conspicuous number of people already practicing such a sport matter (Devine et al. 2010). Indeed, other practitioners represent an interesting customer base for any sport-related entrepreneurial venture. Professional athletes are also additionally advantaged in such situations as their fame may attract customers wishing to learn more about the sport (Toffoletti and Thorpe 2018). Second, events organized in a specific area may motivate people to start practicing a sport (Terjesen 2008). Then, new opportunities for someone who is already an expert in such a sport will multiply as a consequence of the sport 'euphoria' caused by the event (Devine et al. 2010).

It is clear that among the environmental conditions fostering sport entrepreneurship, there are two major aspects to be inquired: the role of government and its policies in ensuring sport infrastructures availability (Wicker et al. 2009; Ratten 2017, 2019). Such importance has clearly been supported by extant literature. Wicker et al. (2009), on the one hand, identified how the existence of sport infrastructures may amplify customers' desire to practice a sport. Thus, the arousal of a greater customer base may surely benefit the existing entrepreneurs in the sport industry (Rütten et al. 2000). The role of government and its policies is then twofold. First of all, the government policies may influence the overall health of the population - indeed, a more active population is less prone to experience health problems such as strokes and other diseases (Sallis et al. 2000). Second, thanks to such kind of policies, the government may indirectly foster the intention to start a sport-related venture. Entrepreneurs may therefore decide to start a new venture to satisfy increasing demand for practicing a sport at either semiprofessional or professional level (Wicker et al. 2009). According to Ratten (2019), government policies also have a direct role in influencing the emergence of new ventures in the sport industry. Indeed, the government may decide to support sports by the creation of new infrastructures and, consequently, also develop policies for entrepreneurs wishing to use them. Such a phenomenon is related to social objectives of the government agenda concerning social inclusion and job creation. The literature, however, paid scant attention so far to the empirical investigation of this phenomenon (Ratten 2019). Scholars, then, should also focus on the analysis of the role of governments and policies by observing data concerning the success of businesses starting as a consequence.

Yet, as assessed by any other stream of entrepreneurship literature, the third substream of research concerns entrepreneurial education and how this may represent an accelerator for the creation of entrepreneurial ventures by sportspeople. However, while sportspeople may share common traits with entrepreneurs, they also usually lack business skills (Neergaard and Krueger 2008). As a matter of fact, most sportspeople have spent their youth in sport training and practising. This may have left less time to learn about the basics of business, thus refraining them from starting new ventures. In this perspective, several papers pointed out how the role of universities in educating athletes, and students enrolled in sport courses, in business-related and entrepreneurial topics. This kind of education creates a balanced set of skills - both soft and hard (Fayolle et al. 2010) - to identify new opportunities arising in the market, as much as, to better run the venture from an economical and financial perspective. Hence, entrepreneurial education may provide sportspeople with the skills they need to get financing, realize a business plan, and to maintain economic and financial equilibrium. Sport entrepreneurial ventures started by competent people then have a greater chance of 
survival in the competitive arena. There is a need to develop ad hoc entrepreneurial education programs for sportspeople or students of sport-management or sport-related courses. In fact, entrepreneurial ventures are more likely to prosper when the sportspeople are effectively trained with the skill and competences needed to start a venture (Ratten and Jones 2018). So, how can educators foster the growth of sportrelated entrepreneurial ventures? Is it possible to create an entrepreneurial learning environment tailored on the needs of the sportspeople? Similar to other contexts such as military veterans (Kerrick et al. 2014), what are the effective entrepreneurial education programme for sportspeople and sport professionals?

However, entrepreneurial education is a broad definition that includes a wide spectrum of pedagogies and even thematic educational purposes. For example, the Quality Assurance Agency in UK (QAA) divides entrepreneurial education in enterprise and entrepreneurship educational types (Quality Assurance Agency (QAA) 2018). The first type of education has a goal to promote innovative ideas along with creativity thinking and should stimulate open-minded mind-sets; the second one is instead specifically aimed directly towards the venturing process and thus also the exploitation of opportunities. Thus, relevant questions are also posed to sport entrepreneurial education. Is more beneficial having an enterprise or an entrepreneurship education for sportspeople? What are the specific pedagogies that may stimulate or appeal to more sportspeople? For what has been said, sportspeople may lack business skills and thus an entrepreneurship education could be required (Ratten and Jones 2018). However, sport entrepreneurs, especially those who are self-employed, may already have experience of managing a business or their career while they may lack the ability to think about it in a more entrepreneurial way. In this case, enterprise education could instead be prominent. Pellegrini et al. (2019) further explode the concept of entrepreneurial education. The authors fundamentally kept the division of enterprise and entrepreneurship education, translated the cognitive state of the entrepreneurs, a more practical-oriented sphere thus behaviours. In addition, they also reframed the cognitive sphere in personal attitudes, i.e. orientations for acting and meta-competencies, i.e. ability to act and the behavioural sphere into strategizing, i.e. goals orientation and organising, and the ability to master proper means. This further classification may add some more specific questions about how to structure the entrepreneurial education for sportspeople: 1) how does sportspeople perceive their attitudes towards entrepreneurship? How can entrepreneurial education foster this aspect, using sport-related experiences? 2) What are the meta-competencies already developed in sportspeople? (e.g. teamwork, leadership?) and consequentially which are those to be developed? (creativity, ethical sensitivity?) 3) how can sportspeople learn to practical strategizing their goals? 4) How to train business skills in sportspeople? How to raise awareness about legal and financial constraints and limitation in launching sport-related ventures?

Finally, the fourth sub-stream includes effects of the emergence of sport entrepreneurial ventures, expressly showing how sport entrepreneurial ventures may have an intense social impact (Ratten 2016). Sport is seen as a way to include disadvantaged people in communal activities, therefore as an activity to foster social inclusion (Bjärsholm 2017) to even keep social stability and peace (Svensson and Seifried 2017). Similarly, sport is an activity capable of providing younger people entertainment and socialization in a healthy way as they require (Shilbury 2011a). Hence, sport has a social valance capable of triggering community and societal development (Ratten 
2017). Yet, sport events and sport entrepreneurship offer another relevant aspect of interest for the public sphere and it is the opportunity for recreation and entrainment that can also fuel tourism, leisure, and local development (Gammon and Robinson 2003), purely related to economic goals (Ciomaga 2013).

This is what happens in elite sports, where economic concerns and returns prevail over the central social core (Chalip 2006). This poses a serious challenge for sport entrepreneurs that may struggle in managing such different identities and institutional logics (Svensson 2017). From social entrepreneurship studies (e.g. Stevens et al. 2014), such conflicting logics are also mutually excluding. Thus, a strong focus either on the social or commercial orientations are rather mutually exclusive and follow the progression of the professionalization of the sport entrepreneur/manager, starting from a purely social to an entirely commercial orientation (Shilbury and Ferkins 2011). However, there are several questions unsolved. For example, how to determine the possible critical moment to shift paradigm in sport entrepreneurship? Are there some factors/ insights that may help sport entrepreneurs to identify tension situations for which is necessary to shift the business paradigm? How can social business models be converted into a commercial structure? How can traditional beneficiaries (sport as a social mission) be turned into actual customers (sport as a commercial purpose)? Does the risk of identity loss in sport entrepreneurship differ from other social enterprises?

Our findings can be summarized in the following framework (Fig. 3). The colour of the boxes refers to the colour of the cluster from which the insight has been derived.

In the proposed framework, it is possible to observe how the sport entrepreneurship stream of research is articulated, and the main topics/sub-streams that have been so far been explored. Nevertheless, while developing these sub-streams and elements, we also showed gaps that need to be addressed, posing specific and domain-related research questions to set the research agenda for this sport entrepreneurship.

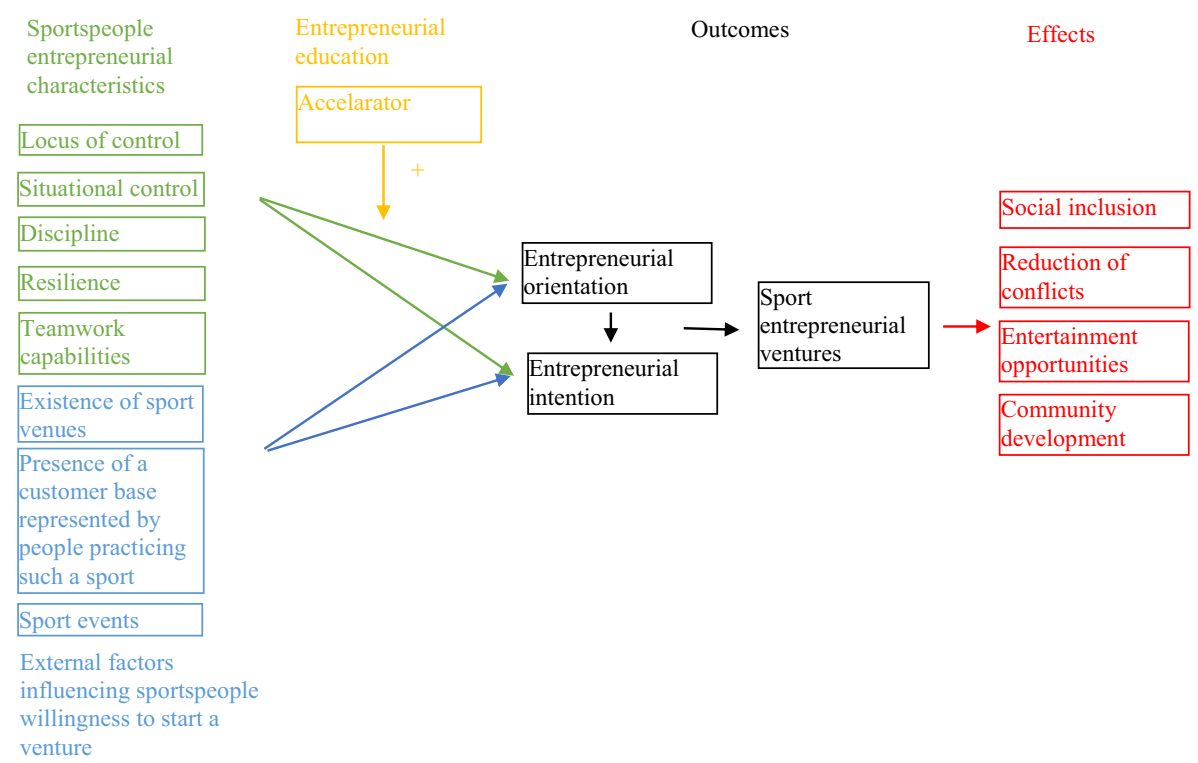

Fig. 3 An interpretative framework reassuming the dynamics of sport entrepreneurship phenomenon 
However, it is important to underline how sport entrepreneurship as field of study, can contribute in the development of a more general sport management field. As several scholars claim (e.g. Ciomaga 2013), there is a need for specific models for sport management and entrepreneurial aspects of the sport may support in such an effort (Ratten 2017, p. 642). For this reason, we can also briefly propose some general research questions embracing the whole field.

One important aspect is that the sport management needs to embrace the digital transformation that deeply affected many other industries. How companies that are working in the field of sport would be influenced by the digital transformation? What about the connection of digitalization with mega events? (Whannel 2009). The "Future of Global Sport" report, made by the Association of Summer Olympic International Federations (2019), poses similar concern directly to sport managers/entrepreneurs in relation to their ability to re-adapt their business models to the digital transformation, so to fully exploit opportunities and have a better customer-reaching ability. Sport entrepreneurship with its intrinsic vocation towards change and innovation is surely central to the debate (Miragaia, Ferreira \& Ratten 2017).

Another aspect called for further investigation is how sport entrepreneurship is the necessary shifting of the strategic focus of sport management (Chadwick 2009). Most of the time in sport, the strategic orientation is dedicated to the 'product' thus promoting the sport itself. However, a more managerial approach to this focus should be dedicated to customers and the market orientation, such as trying to address issues relating to fans' experience and promoting lifetime value for customers. How sport organisations can shift their cultural values and thus their strategic focus? What are the marketing strategies to support such a shift? While the marketing of sports is stable topic in sport management literature (Shilbury 2011a, b), sport entrepreneurship is more dynamically interested in this marketing concern so to turn it into opportunities (Ratten 2016). Yet the problem of the hybrid nature, commercial and social, of many sport entrepreneurial ventures can also be an interesting perspective to analyse innovative solutions for managing different identities (Jones et al. 2017).

Finally, gender and diversity are recurrent topics in sport management and emerged as one of the future trends for the field (Ciomaga 2013). Sport entrepreneurship has embryonically started talking about this concern (e.g. Micelotta et al. 2018; Ratten and Miragaia 2019) pointing out how female managers and athletes may find further difficulties in establishing themselves amidst the competition. Sport entrepreneurship using traditional female entrepreneurship models, e.g. the ' $5 \mathrm{M}$ ' model (Brush et al. 2009), may better explain the specific conditions of females in the sport industry when in leadership roles.

In addition to this theoretical development, the proposed framework also provides some interesting insights for practitioners involved in sport and sport entrepreneurship education. In particular, first raising awareness of the potential of sportspeople in relation to entrepreneurship, i.e. they already share the most of necessary traits deemed fundamental to become an entrepreneur. Second, it may help the organisers of education programs to develop specific courses. Indeed, as it is possible to observe from the framework, sport entrepreneurial education courses could mostly focus on financial, business administration, and management skills sportspeople are missing. However, this is a standard solution. Instead, participants' needs have to be taken into consideration in designing such courses/training. Finally, pondering the contingent situation; on 
the one hand, the environmental conditions faced by sportspeople to start their ventures, as much as the public attention dedicated to the sport (Chalip 1995, 2006). On the other hand, the 'business conditions' that the sport entrepreneurial venture is facing and if the organisation is ready or needs to start thinking of a possible shifting logic from a pure non-profit orientation to a (more) commercial one (Stevens et al. 2014).

\section{Conclusion and limitations}

The present research contributes to sport entrepreneurship research by proving a systematization of the several streams of knowledge. In contrast to previous and valuable reviews/bibliometric studies on the topic (e.g. Huertas González-Serrano et al. 2019), our paper provides insights about the main sub-streams existing within sport entrepreneurship -contributing further to establishing foundational building blocks for the discipline. Additionally, it contributes to literature by identifying the relationship between such sub-streams. In this perspective, it was possible to observe how clusters are nested, which is significant proof of the fact that scholars doing research on sport entrepreneurship dialogue together and built their research on a common pool of seminal research. Finally, the research contributes to literature thanks to the identification of a framework reassuming factors triggering/hindering sport entrepreneurship, either of an internal or an external nature, entrepreneurial education as an accelerator, and the outcomes of the diffusion of sport related entrepreneurial ventures. For each of these areas, we also proposed significant research avenues and questions, as much as general concerns that can compare sport entrepreneurship and sport management evolutions.

This research presents the limitations of any other bibliometric research (Caputo et al. 2018; Sassetti et al. 2018). Specifically, the authors simplified a complex body of knowledge in an attempt to present it more succinctly. In doing so, some information is discarded in order to allow for a graphical representation of data and an easy use of the insights presented (van Eck and Waltman 2009). In fact, the aim of the present study is to provide a map to guide researchers who are approaching the field of sport entrepreneurship and, as presented in the discussion part, there is a full set of underexplored questions that can inspire further development of a promising field.

\section{References}

Aghaei Chadegani, A., Salehi, H., Yunus, M., Farhadi, H., Fooladi, M., Farhadi, M., \& Ale Ebrahim, N. (2013). A comparison between two main academic literature collections: Web of science and Scopus databases. Asian Social Science, 9(5), 18-26 https://ssrn.com/abstract=2257540.

Ahmed, M. (2018, September 16), Ronaldo: Why Juventus gambled $€ 100 \mathrm{~m}$ on a future payday, Financial Times, Retrieved on-line https://www.ft.com/content/cc72b6a6-b5b9-11e8-b3ef-799c8613f4a1. (Accessed on Nov. 2018).

Ajzen, I. (1991). The theory of planned behavior. Organizational Behavior and Human Decision Processes, 50(2), 179-211. https://doi.org/10.1016/0749-5978 (91)90020-T.

Association of Summer Olympic International Federations. (2019). Future of Global Sport. Retrieved from https://www.asoif.com/sites/default/files/download/future_of_global_sport.pdf 
Baumol, W. J. (1996). Entrepreneurship: Productive, unproductive, and destructive (reprinted from journal of political economy, vol 98, pg 893-921, 1990). Journal of Business Venturing, 11(1), 3-22. https://doi. org/10.1016/0883-9026 (94)00014-x.

Bjärsholm, D. (2017). Sport and social entrepreneurship: A review of a concept in Progress. Journal of Sport Management, 31(2), 191-206. https://doi.org/10.1123/jsm.2017-0007.

Briedenhann, J. (2011). Economic and tourism expectations of the 2010 FIFA world cup - A resident perspective. Journal of Sport and Tourism, 16(1), 5-32. https://doi.org/10.1080/14775085.2011.568085.

Brush, C. G., De Bruin, A., \& Welter, F. (2009). A gender-aware framework for women's entrepreneurship. International Journal of Gender and Entrepreneurship, 1(1), 8-24. https://doi.org/10.1108 /17566260910942318.

Caputo, A., Marzi, G., Pellegrini, M. M., \& Rialti, R. (2018). Conflict management in family businesses: A bibliometric analysis and systematic literature review. International Journal of Conflict Management, 29(4), 519-542. https://doi.org/10.1108/IJCMA-02-2018-0027.

Cardon, M., Zietsma, S., Saparito, C., Matherne, P., \& B. P. \& Davis, C. (2005). A tale of passion: New insights into entrepreneurship from a parenthood metaphor. Journal of Business Venturing, 20(1), 23-45. https://doi.org/10.1016/j.jbusvent.2004.01.002.

Cardon, M. S., Wincent, J., Singh, J., \& Drnovsek, M. (2009). The nature and experience of entrepreneurial passion. Academy of Management Review, 34(3), 511-532. https://doi.org/10.5465/amr.2009.40633190.

Chadwick, S. (2009). From outside lane to inside track: Sport management research in the twenty-first century. Management Decision, 47(1), 191-203. https://doi.org/10.1108/00251740910929786.

Chalip, L. (1995). Policy analysis in sport management. Journal of Sport Management, 9(1), 1-13. https://doi. org/10.1123/jsm.9.1.1.

Chalip, L. (2006). Toward a distinctive sport management discipline. Journal of Sport Management, 20(1), 121. https://doi.org/10.1123/jsm.20.1.1.

Ciomaga, B. (2013). Sport management: A bibliometric study on central themes and trends. European Sport Management Quarterly, 13(5), 557-578. https://doi.org/10.1080/16184742.2013.838283.

Cohen, A., \& Peachey, J. W. (2015). The making of a social entrepreneur: From participant to cause champion within a sport-for-development context. Sport Management Review, 18(1), 111-125. https://doi. org/10.1016/j.smr.2014.04.002.

Crick, D. and Crick, J. (2016), Coopetition at the sports marketing/entrepreneurship interface: A case study of a Taekwondo organisation, Marketing Intelligence \& Planning, Vol. 34 No. 2, pp. 169-187.

Dabic, M., González-Loureiro, M., \& Furrer, O. (2014). Research on the strategy of multinational enterprises: Key approaches and new avenues. BRQ Business Research Quarterly, 17(2), 129-148. https://doi. org/10.1016/j.brq.2013.09.001.

Devine, A., Bolan, P., \& Devine, F. (2010). Online destination marketing: Maximising the tourism potential of a sports event. International Journal of Sport Management and Marketing, 7(1-2), 58-75. https://doi. org/10.1504/IJSMM.2010.029712.

do Paço, A., Ferreira, J. M., Raposo, M., Rodrigues, R. G., \& Dinis, A. (2013). Entrepreneurial intentions: Is education enough? International Entrepreneurship and Management Journal, 11(1), 57-75. https://doi. org/10.1007/s1 1365-013-0280-5.

Eisenhardt, K. M., \& Martin, J. A. (2000). Dynamic capabilities: What are they? Strategic Management Journal, 21(10-11), 1105-1121. https://doi.org/10.1002/1097-0266 (200010/11)21:10/11<1105::AIDSMJ133>3.0.CO;2-E.

European Commission (2017). Resolution of the Council and of the Representatives of the Governments of the Member States, meeting within the Council, on the European Union Work Plan for Sport (1 July 2017-31 December 2020). Official journal C 189, 60 (15/6/2017), 5-14. Retrieved at https://eur-lex. europa.eu/legal-content/EN/TXT/?uri=CELEX:42017Y0615(01).

Eurostat (2018). Employment in sport. Retrieved from https://ec.europa.eu/eurostat/statisticsexplained/pdfscache/44953.pdf

Fagerberg, J., Fosaas, M., \& Sapprasert, K. (2012). Innovation: Exploring the knowledge base. Research Policy, 41(7), 1132-1153. https://doi.org/10.1016/j.respol.2012.03.008.

Fayolle, A., Basso, O., \& Bouchard, V. (2010). Three levels of culture and firms' entrepreneurial orientation: A research agenda. Entrepreneurship and Regional Development, 22(7-8), 707-730. https://doi. org/10.1080/08985620903233952.

Fernandez, L., Bedia, A. M. S., \& Perez, M. P. (2015). Entrepreneurship and family firm research: A Bibliometric analysis of an emerging field. Journal of Small Business Management, 10(1), 1-18. https://doi.org/10.1111/jsbm.12161. 
Franco, M., \& Pessoa, N. (2014). University sports partnerships as collaborative entrepreneurship: An exploratory case study. Administration and Society, 46(8), 885-907. https://doi.org/10.1177 /0095399713481597.

Gammon, S., \& Robinson, T. (2003). Sport and tourism: A conceptual framework. Journal of Sport and Tourism, 8(1), 21-26. https://doi.org/10.1080/14775080306236.

Gartner, W., Starr, J., \& Bhat, S. (1999). Predicting new venture survival: An analysis of "anatomy of a startup." cases from Inc. Magazine. Journal of Business Venturing, 14(2), 215-232. https://doi.org/10.1016 /S0883-9026 (97)00063-3.

Gonzalez Serrano, M. H., Valantine, I., Perez Campos, C., Aguado Berenguer, S., Calabuig Moreno, F., \& Crespo Hervas, J. J. (2016). The influence of gender and academic training in the entrepreneurial intention of physical activity and sport sciences students. Intangible Capital, 12(3), 759-788. https://doi. org/10.3926/ic.783.

González-Serrano, M. H., Crespo Hervás, J., Pérez-Campos, C., \& Calabuig-Moreno, F. (2017). The importance of developing the entrepreneurial capacities in sport sciences university students. International Journal of Sport Policy, 9(4), 625-640. https://doi.org/10.1080/19406940.2017.1316762.

González-Serrano, M. H., Valantine, I., Hervás, J. C., Pérez-Campos, C., \& Moreno, F. C. (2018). Sports university education and entrepreneurial intentions: A comparison between Spain and Lithuania. Education and Training, 60(5), 389-405. https://doi.org/10.1108/ET-12-2017-0205.

Hemme, F., Morais, D. G., Bowers, M. T., \& Todd, J. S. (2017). Extending sport-based entrepreneurship theory through phenomenological inquiry. Sport Management Review, 20(1), 92-104. https://oi. org/10.1016/j.smr.2016.07.005.

Hennekam, S. (2015). Challenges of older self-employed workers in creative industries: The case of the Netherlands. Management Decision, 53(4), 876-891. https://doi.org/10.1108/17566260910942318.

Huertas González-Serrano, M., Jones, P., \& Llanos-Contrera, O. (2019). An overview of sport entrepreneurship field: A bibliometric analysis of the articles published in the web of science. Sport in Society, ahead of printing, 1-18. https://doi.org/10.1080/17430437.2019.1607307.

Jones, P., \& Jones, A. (2014). Attitudes of sports development and sports management undergraduate students towards entrepreneurship: A university perspective towards best practice. Education and Training, 56, 716-732. https://doi.org/10.1108/ET-06-2014-0060.

Jones, P., Jones, A., Williams-Burnett, N., \& Ratten, V. (2017). Let's get physical: Stories of entrepreneurial activity from sports coaches/instructors. International Journal of Entrepreneurship and Innovation, 18(4), 219-230. https://doi.org/10.1177/1465750317741878.

Kautonen, T., Kibler, E., \& Minniti, M. (2017). Late-career entrepreneurship, income and quality of life. Journal of Business Venturing, 32(3), 318-333. https://doi.org/10.1016/j.jbusvent.2017.02.005.

Kellett, P., \& Russell, R. (2009). A comparison between mainstream and action sport industries in Australia: A case study of the skateboarding cluster. Sport Management Review, 12(2), 66-78. https://doi.org/10.1016 j.smr.2008.12.003.

Kenny, B. (2015). Meeting the entrepreneurial learning needs of professional athletes in career transition. International Journal of Entrepreneurial Behaviour and Research, 21(2), 175-196. https://doi. org/10.1108/IJEBR-07-2013-0113.

Kerrick, S. A., Cumberland, D., Church-Nally, M., \& Kemelgor, B. (2014). Military veterans marching towards entrepreneurship: An exploratory mixed methods study. The International Journal of Management Education, 12(3), 469-478.

Lyras, A., \& Welty Peachey, J. (2011). Integrating sport-for-development theory and praxis. Sport Management Review, 14(4), 311-326. https://doi.org/10.1016/j.smr.2011.05.006.

Mackenzie, S. B. (2008). Scholarly Influence in the Field of Management: A Bibliometric Analysis of the Determinants of University and Author Impact in the Management Literature in t. Journal of Management, 34(1), 641-720. https://doi.org/10.1177/0149206308319533.

Marzi, G., Dabić, M., Daim, T., \& Garces, E. (2017). Product and process innovation in manufacturing firms: A 30-year bibliometric analysis. Scientometrics, 113(2), 673-704. https://doi.org/10.1007/s11192-0172500-1.

Marzi, G, Caputo, A., Garces, E., \& Dabic, M. (2018). A three decade mixed-method Bibliometric investigation of the IEEE transactions on engineering management. IEEE Transactions on Engineering Management. https://doi.org/10.1109/TEM.2018.2870648.

Micelotta, E., Washington, M., \& Docekalova, I. (2018). Industry gender imprinting and new venture creation: The liabilities of women's leagues in the sports industry. Entrepreneurship: Theory and Practice, 42(1), 94-128. https://doi.org/10.1177/1042258717732778. 
Miragaia, D., Ferreira, J., \& Ratten, V. (2017). Sport event sponsorship and policy: A social entrepreneurship and corporate social responsibility perspective. International Journal of Sport Policy and Politics, 29(4), 613-623.

Misener, K. E., \& Misener, L. (2017). Grey is the new black: Advancing understanding of new organizational forms and blurring sector boundaries in sport management. Journal of Sport Management, 31(2), 125132. https://doi.org/10.1123/jsm.2017-0030.

Mitchell, R. K. (2005). Tuning up the global value creation engine: The road to excellence in international entrepreneurship education. In Advances in entrepreneurship, firm emergence and growth. Bingley: Emerald Publishing Ltd.

Napier, N. K., \& Nilsson, M. (2006). The development of creative capabilities in and out of creative organizations: Three case studies. Creativity and Innovation Management, 15(3), 268-278. https://doi. org/10.1111/j.1467-8691.2006.00396.x.

Neale, W. C. (1964). The peculiar economics of professional sports. Quarterly Journal of Economics, 78(1), 1-14. https://doi.org/10.2307/1880543.

Neergaard, H., \& Krueger, N. F. (2008). Still playing the game? In SSRN. https://doi.org/10.2139 /ssrn.1146742.

Newcombe, P. A., \& Boyle, G. J. (1995). High school students' sport personalities: Variations across participation level, gender, type of sport, and success. International Journal of Sport Psychology, 26, 277-294 http://epublications.bond.edu.au/hss_pubs/802.

Núñez-Pomar, J., Prado-Gascó, V., Añó Sanz, V., Crespo Hervás, J., \& Calabuig Moreno, F. (2016). Does size matter? Entrepreneurial orientation and performance in Spanish sports firms. Journal of Business Research, 69(11), 5336-5341. https://doi.org/10.1016/j.jbusres.2016.04.134.

Pellegrini M. M., Ciappei C., Marzi G., Dabić M., \& Egri C. P. (2019), A philosophical approach to entrepreneurship education: A model based on Kantian and Aristotelian thought, International Journal of Entrepreneurship and Small Business, ahead of printing, 1-29.

Penrose, E. T. (1959). The cornerstones of competitive advantage: A resource-based view. Strategic Management Journal, 14(3), 179-194. https://doi.org/10.1002/smj.4250140303.

Quality Assurance Agency (QAA) (2018). Enterprise and entrepreneurship education: Guidance for UK higher education providers. Retrievable at: https:/www.qaa.ac.uk/docs/qaas/enhancement-anddevelopment/enterprise-and-entrpreneurship-education-2018.pdf

Raglin, J. S. (2001). Psychological factors in sport performance. Sports Medicine, 31(12), 875-890.

Ranfagni, S., \& Runfola, A. (2018). Connecting passion: Distinctive features from emerging entrepreneurial profiles. Journal of Business Research. https://doi.org/10.1016/j.jbusres.2018.04.018.

Ratten, V. (2010). Developing a theory of sport-based entrepreneurship. Journal of Management \& Organization, 16(4), 557-565. https://doi.org/10.1017/S1833367200001930.

Ratten, V. (2011a). A social perspective of sports-based entrepreneurship. International Journal of Entrepreneurship and Small Business, 12(3), 314-326. https://doi.org/10.1504/IJESB.2011.039010.

Ratten, V. (2011b). Sport-based entrepreneurship: Towards a new theory of entrepreneurship and sport management. International Entrepreneurship and Management Journal, 7(1), 57-69. https://doi. org/10.1007/s11365-010-0138-z.

Ratten, V. (2012a). Guest editor's introduction: Sports entrepreneurship: Towards a conceptualisation. International Journal of Entrepreneurial Venturing, 4(1), 1-8. https://doi.org/10.1504 /IJEV.2012.044814.

Ratten, V. (2012b). Sport entrepreneurship: Challenges and directions for future research. International Journal of Entrepreneurial Venturing, 4(1), 65-84. https://doi.org/10.1504/IJEV.2012.044819.

Ratten, V. (2015). Athletes as entrepreneurs: The role of social capital and leadership ability. International Journal of Entrepreneurship and Small Business, 25(4), 442-463. https://doi.org/10.1504 /IJESB.2015.070217.

Ratten, V. (2016). The dynamics of sport marketing. Marketing Intelligence \& Planning, 34(2), 162-168. https://doi.org/10.1108/MIP-07-2015-0131.

Ratten, V. (2017). Entrepreneurial sport policy. International Journal of Sport Policy, 9(4), 641-648. https://doi.org/10.1080/19406940.2017.1334693.

Ratten, V. (2019). Sport entrepreneurship and public policy: Future trends and research developments. Journal of Entrepreneurship and Public Policy, 8(1), 207-216. https://doi.org/10.1108/JEPP-D-18-00099.

Ratten, V., \& Jones, P. (2018). Future research directions for sport education: Toward an entrepreneurial learning approach. Education+ Training, 60(5), 490-499. https://doi.org/10.1108/ET-02-2018-0028.

Ratten, V. \& Miragaia D. (2019). Entrepreneurial passion amongst female athletes. Journal of Small Business and Entrepreneurship, ahead of printing, 1-19. https://doi.org/10.1080/08276331.2018.1551460. 
Rialti, R., Pellegrini, M. M., Caputo, A., \& Dabic, M. (2017). Entrepreneurial education and internationalisation of firms in transition economies: A conceptual framework from the case of Croatia. World Review of Entrepreneurship, Management and Sustainable Development, 13, 2-3. https://doi. org/10.1504/WREMSD.2017.083027.

Rialti, R., Caliandro, A., Zollo, L., \& Ciappei, C. (2018). Co-creation experiences in social media brand communities. Spanish Journal of Marketing - ESIC, 22(2), 122-141. https://doi.org/10.1108/SJME-032018-0011.

Ross, S. R., Rausch, M. K., \& Canada, K. E. (2003). Competition and cooperation in the five-factor model: Individual differences in achievement orientation. The Journal of Psychology, 137(4), 323-337.

Rütten, A., Lüschen, G., von Lengerke, T., Abel, Z., Kannas, L., Diaz, J. A. R., Vinck, J., \& van der Zee, J. (2000). Health promotion policy in Europe. In Rationality, impact, and evaluation. München: Oldenbourg.

Sallis, J. F., Prochaska, J. J., \& Taylor, W. C. (2000). A review of correlates of physical activity of children and adolescents. Medicine and Science in Sports and Exercise, 32, 963-975 0195-9131/00/3205-0963/0.

Sassetti, S., Marzi, G., Cavaliere, V., \& Ciappei, C. (2018). Entrepreneurial cognition and socially situated approach: A systematic and bibliometric analysis. Scientometrics, 116(3), 1675-1718. https://doi. org/10.1007/s11192-018-2809-4.

Schulenkorf, N. (2017). Managing sport-for-development: Reflections and outlook. Sport Management Review, 20(3), 243-251. https://doi.org/10.1016/j.smr.2016.11.003.

Schumpeter, J. A. (1942). Capitalism, socialism, and democracy: Harper and Brothers, New York. In Unwin university books. https://doi.org/10.3791/2330.

Shane, S., \& Venkataraman, S. (2000). The promise of entrepreneurship as a field of study. Academy of Management Review, 25(1), 217-226. https://doi.org/10.2307/259271.

Shilbury, D. (2011a). A bibliometric analysis of four sport management journals. Sport Management Review, 14(4), 434 452. https://doi.org/10.1016/j.smr.2010.11.005.

Shilbury, D. (2011b). A bibliometric study of citations to sport management and marketing journals. Journal of Sport Management, 25(5), 423-444. https://doi.org/10.1123/jsm.25.5.423.

Shilbury, D., \& Ferkins, L. (2011). Professionalisation, sport governance and strategic capability. Managing Leisure, 16(2), 108-127. https://doi.org/10.1080/13606719.2011.559090.

Smart, P., Tranfield, D., \& Denyer, D. (2003). Towards a methodology for developing evidence-informed management knowledge by means of systematic review. British Journal of Management, 14(3), 207-222. https://doi.org/10.1111/1467-8551.00375.

Stambaugh, J., \& Mitchell, R. (2018). The fight is the coach: Creating expertise during the fight to avoid entrepreneurial failure. International Journal of Entrepreneurial Behaviour and Research, 24(5), 994 1015. https://doi.org/10.1108/IJEBR-09-2016-0287.

Stevens, R., Moray, N., \& Bruneel, J. (2014). The social and economic Mission of social enterprises: Dimensions, measurement, validation, and relation. Entrepreneurship Theory and Practice, 39(5), 1051-1082. https://doi.org/10.1111/etap.12091.

Svensson, P. G. (2017). Organizational hybridity: A conceptualization of how sport for development and peace organizations respond to divergent institutional demands. Sport Management Review, 20(5), 443454. https://doi.org/10.1016/j.smr.2017.03.004.

Svensson, P. G., \& Seifried, C. S. (2017). Navigating plurality in hybrid organizing: The case of sport for development and peace entrepreneurs. Journal of Sport Management, 31(2), 176-190. https://doi. org/10.1123/jsm.2016-0129.

Teixeira, A. A. C., \& Forte, R. P. (2017). Prior education and entrepreneurial intentions: The differential impact of a wide range of fields of study. Review of Managerial Science, 11(2), 353-394. https://doi. org/10.1007/s11846-015-0188-2.

Terjesen, S. (2008). Venturing beyond the marathon: The entrepreneurship of ultrarunning and the IAU world cup in Korea. Asian Business and Management, 7(2), 225-241. https://doi.org/10.1057/abm.2008.2.

Toffoletti, K., \& Thorpe, H. (2018). The athletic labour of femininity: The branding and consumption of global celebrity sportswomen on Instagram. Journal of Consumer Culture, 18(2), 298-316. https://oi. org/10.1177/1469540517747068.

Tyson, B., Hayle, C., Truly, D., Ann Jordan, L., \& Thame, M. (2005). West indies world cup cricket: Hallmark events as catalysts for community tourism development. Journal of Sport and Tourism, 10(4), 323-334. https://doi.org/10.1080/14775080600806653.

van Bottenburg, M., \& Salome, L. (2010). The indoorisation of outdoor sports: An exploration of the rise of lifestyle sports in artificial settings. Leisure Studies, 29(2), 143-160. https://doi.org/10.1080 /02614360903261479. 
van Eck, N. J., \& Waltman, L. (2009). How to normalize cooccurrence data ? An analysis of some wellknown similarity measures. Journal of the American Society for Information Science and Technology, $60(8), 1-17$.

van Eck, N. J., \& Waltman, L. (2010). Software survey: VOSviewer, a computer program for bibliometric mapping. Scientometrics, 84(2), 523-538. https://doi.org/10.1007/s11192-009-0146-3.

van Eck, N. J., Waltman, L., van Den Berg, J., \& Kaymak, U. (2006). Visualizing the computational intelligence field. IEEE Computational Intelligence Magazine, 1(4), 6-10. https://doi.org/10.1109/CIM.2006.248043.

Whannel, G. (2009). Television and the transformation of sport. The Annals of the American Academy of Political and Social Science, 625(1), 205-218. https://doi.org/10.1177/0002716209339144.

Wicker, P., Breuer, C., \& Pawlowski, T. (2009). Promoting sport for all to age-specific target groups: The impact of sport infrastructure. European Sport Management Quarterly, 9(2), 103-118. https://doi. org/10.1080/16184740802571377.

Wolfe, M. T., \& Shepherd, D. A. (2015). "Bouncing Back" from a loss: Entrepreneurial orientation, emotions, and failure narratives. Entrepreneurship: Theory and Practice, 39(3), 675-700. https://doi.org/10.1111 /etap.12057.

Zollo, L., Rialti, R., Ciappei, C., \& Boccardi, A. (2018). Bricolage and social entrepreneurship to address emergent social needs: A “deconstructionist” perspective. Journal of Entrepreneurship, Management and Innovation, 14(2), 19-47. https://doi.org/10.7341/20181422.

Zupic, I., \& Čater, T. (2015). Bibliometric methods in management and organization. Organizational Research Methods, 18(3), 429-472. https://doi.org/10.1177/1094428114562629.

Publisher's note Springer Nature remains neutral with regard to jurisdictional claims in published maps and institutional affiliations. 